\title{
FIRST REPORT ON FIBRINOLYTIC AND THROMBOLYTIC ACTIVITY OF EUTYPHOEUS GAMMIEI AN EARTHWORM SPECIES COLLECTED FROM TRIPURA, NORTHEAST INDIA
}

\author{
MADHUSUDAN DEBNATH, SUSMITA SAHA, SAMIR KUMAR SIL*
}

Department of Human Physiology, Tripura University, Suryamaninagar - 799 002, Tripura, India. Email: tbc2006@rediffmail.com

Received: 05 June 2018, Revised and Accepted: 09 July 2018

ABSTRACT

Objective: The present investigation for the first time evaluated the in vitro fibrinolytic and thrombolytic activities of crude extracts from Eutyphoeus gammiei, native, large size earthworm of Tripura, Northeast, India. The present study was designed to evaluate the therapeutic use of the organism E. gammiei as a source of fibrinolytic and thrombolytic agent(s).

Methods: The fibrinolytic activity was studied using by fibrin plate and zymography assays. Thrombolytic assay was carried out according to Prasad et al. (2006) using whole blood.

Results: The results obtained clearly indicated E. gammiei as a potential source of fibrinolytic and thrombolytic agents. Both in fibrin plate assay and thrombolytic assay with whole blood, E. gammiei crude homogenate showed similar and close results in respect to that of streptokinase. Fibrin zymography also showed antifibrinolytic activity with producing clear bands. Dose and time dependency also is evident from the results.

Conclusion: The results of the present study conclude that the studied earthworm species E. gammiei possessed profound fibrinolytic and thrombolytic activity on human blood and E. gammiei might prove to be useful alternative source for the development of new drugs for treatments involving blood coagulation and fibrinolysis.

Keyword: Eutyphoeus gammiei, Earthworm, Fibrinolytic, Thrombolytic activity, North-East India.

(C) 2018 The Authors. Published by Innovare Academic Sciences Pvt Ltd. This is an open access article under the CC BY license (http://creativecommons. org/licenses/by/4. 0/) DOI: http://dx.doi.org/10.22159/ajpcr.2018.v11i11.27739

\section{INTRODUCTION}

Thrombolytic disorders including cerebral stroke and myocardial infarctions have become a serious concern all over the world. Commonly used fibrinolytic agents that dissolve clots are urokinase, streptokinase (ST), and tissue plasminogen activator. These are not specific for fibrin and have adverse and dangerous side effect including severe bleeding and thereby blood loss which may result in death $[1,2]$. On the other hand, earthworm fibrinolytic enzyme, also known as Lumbrokinase (LK), is very specific to fibrin and it does not cause excessive bleeding [1,2]. Lumbrokinase has also shown promise for use in lowering whole blood viscosity and reducing platelets aggregation $[3,4]$. Earthworm fibrinolytic enzymes can be transported into the blood through the intestinal epithelium, and the enzyme works after oral administration [5]. The most common source of earthworm fibrinolytic enzyme is Lumbricus rubellus, Eisenia foetida, and Paritima sp. Isoenzymes constituents of each earthworm may vary depending on the species and living environment which may lead to differences in their activities [6]. Approximately 4400 different species have been identified worldwide. According to Julka et al. [7], of the 12 families of earthworms, the subcontinent has representative genera species form 9 families. In the year 2009 Julka et al. [8] reported that Indian earthworm fauna comprises about 590 species. Altough there are many reports regarding earthworm fibrinolytic enzymes from China, Japan, and other Far-East Countries, there are very few reports from India and almost no report from North East India. This present study intends to explore for the first time fibrinolytic and thrombolytic activity of Eutyphoeus gammiei an earthworm collected from Tripura, Northeast India.

\section{METHODS}

Sample collection and identification

Adult earthworm E. gammiei was collected by hand sorting and digging method by spade from Agartala, Tripura at early morning.
The sample was first identified by Prof. P S Choudhuri, Earthworm Research Laboratory, Department of Zoology, Tripura University. The sample specimen was also submitted to ZSI, Kolkata, for authentication (voucher number- An 5649/1) (Fig. 1).

\section{Collection site}

The sample was collected from Agartala (Shibnagar), Tripura West, India. The site was demarcated using global positioning system (Latitude: $\mathrm{N}=23.82914^{\circ}$ and Longitude: $\mathrm{E}=091.29485^{\circ}$ ) (Fig. 2).

\section{Preparation of earthworm homogenate}

Earthworm E. gammiei was first washed with running tap water and then fed with wet blotting paper for 18-20 h to clear their gut. The gut cleared worms were again washed with distilled water. $20 \%$ gut cleared earthworm homogenate was prepared in $0.2 \mathrm{M}$ phosphate buffered saline (PBS), pH-7.2. Homogenate was filter sterilized before use.

\section{Determination of protein concentration}

Protein concentration was determined following Lowry's et al. method [9].

\section{Fibrinogen degradation assay}

Fibrinolytic activity of the extract was carried out by the fibrin plate method [10]. Fibrin plate was prepared by mixing $6 \mathrm{ml}$ of $0.6 \%$ bovine plasma fibrinogen and $6 \mathrm{ml}$ of $1.5 \%$ agarose containing $10 \mathrm{NIH}$ units of bovine plasma thrombin. $0.1 \mathrm{M}$ phosphate buffer, $\mathrm{pH} 7.4$ was used throughout the experiment. The prepared solution was quickly poured into a $90 \mathrm{~mm}$ diameter Petri plates and allowed to stand for $1 \mathrm{~h}$ at room temperature and labeled as fibrin plate. The earthworm was applied directly into a small pore created in the Petri plate containing artificial fibrin. ST was used as a positive control, and PBS served as negative controls. The Petri plate was incubated at $37^{\circ} \mathrm{C}$ for various lengths of time. Fibrinolytic activity was determined by examining the formation 
of the zone of lysis in the form of a clear hollow in the fibrin plate. Fibrinolytic activity was assessed by measuring the lysis zone. The procedure was repeated 4-5 times.

\section{Sodium dodecyl sulfate-poly acryl amide gel electrophoresis (SDS} PAGE)

SDS PAGE was done to determine the purity and molecular weight of the enzyme, as described by Laemmli [11] using a $5 \%(\mathrm{w} / \mathrm{v})$ stacking and a $10 \%(\mathrm{w} / \mathrm{v})$ separating gels. The molecular weight of the enzyme was estimated using a low molecular weight calibration kit (Bio-Rad) as a marker.

\section{Fibrin zymography assay}

Fibrin zymography was performed as described previously [12] bovine fibrinogen $(0.12 \% \mathrm{w} / \mathrm{v}$, Sigma) dissolved in $20 \mathrm{mM}$ sodium phosphate buffer (pH 7.4) and $100 \mu \mathrm{l}$ of bovine thrombin (10NIH unit ml Sigma) were copolymerized with $12 \%(\mathrm{w} / \mathrm{v})$ acrylamide. $0.32 \%(\mathrm{w} / \mathrm{v})$ bis acrylamide and $375 \mathrm{mM}$ Tris/HCL (pH 8.8) to make the fibrin gel as the running gel. Then $5 \% \mathrm{w} / \mathrm{v} 0$ acrylamide, $0.11 \%(\mathrm{w} / \mathrm{v})$ bis acrylamide, and $330 \mathrm{nM}$ Tris/HCL (pH 6.8) (no fibrinogen) were used for the stacking gel, which was poured into a mini-gel cast (Bio-Rad). The samples for analysis were prepared by diluting the culture supernatant 5 -fold with zymogram sample buffer (0.5M Tris/HCL, pH 6.8, 10\% SDS, $20 \%$ SDS, $20 \%$ glycerol, and 05.\% Bromophenol Blue) [13]. After the prepared samples $(10 \mu \mathrm{l})$ were loaded into the wells, electrophoresis (Laemmli, 1970) was carried out in the cold room $\left(4^{\circ} \mathrm{C}\right)$ at a constant $12 \mathrm{~mA}$. After electrophoresis, the gel was incubated for $30 \mathrm{~min}$ at room temperature on a rotary shaker in $50 \mathrm{nM}$ Tris/Cl (pH 7.4) which
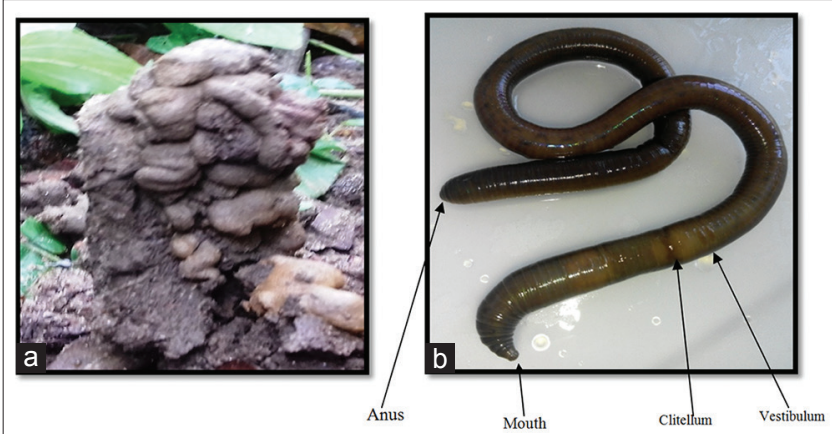

Fig. 1: (a) Earthworm cast of Eutyphoeus gammiei, (b) earthworm E. gammiei contains $2.5 \%$ Triton X-100. The gel was washed with distilled water to remove Triton X-100, and then incubated in Zymogram reaction buffer (30 mM Tris/HCL, pH 7.4, $200 \mathrm{mM} \mathrm{Nacl}, 10 \mathrm{mM} \mathrm{CaCl}_{2}$, and 0.02\% Brij35) at $37^{\circ} \mathrm{C}$ for $12 \mathrm{~h}$. The gel was stained with Coomassie blue for $1 \mathrm{~h}$ and then distained. The digested bands were visualized as the nonstained regions of the fibrin gel.

\section{Thrombolytic assay}

Thrombolytic assay was carried out according to Prasad et al., [14]. Venous blood was drawn from healthy volunteers after taking informed consent $(\mathrm{n}=3)$. $0.5 \mathrm{ml}$ venous blood was put into pre-weighed sterile microcentrifuge tubes and was incubated at $37^{\circ} \mathrm{C}$ for $60 \mathrm{~min}$. After that, serum was removed from the blood clot. Phosphate buffer $(20 \mathrm{mM})$, as blank, and $100 \mu \mathrm{l}$ of homogenate $(0.5 \mathrm{mg} / \mathrm{ml})$ in Phosphate buffer $(20 \mathrm{mM})$ was added separately to the clot and incubated at $37^{\circ} \mathrm{C}$ for $2 \mathrm{~h}, 6 \mathrm{~h}, 12 \mathrm{~h}$, and $24 \mathrm{~h}$. Fluids were removed from the remaining clots, and the tubes were weighed. Thrombolytic activity was calculated by comparing the initial weight of blood clot to that of lysed blood clot. ST was used as positive control.

\section{RESULTS}

Result obtained in the form of clear zone in fibrin plate is presented in Figs. 3 and 5. The diameter of the circles proportionately increased with the increase of incubation time and amount of homogenate (Fig. 5). Clear zone appeared around test and positive control (well no-II, III, IV, V, VI, and VII) whereas, in negative control (well no-I) containing only PBS, no clear zone appeared. Mouth and anus parts of the whole organism showed no activity (Fig. 3.).

When the activity of the homogenate was compared with that of positive control (ST), at the given protein concentration $(0.5 \mathrm{mg} / \mathrm{ml})$, the response of the homogenate was found to be very close to that of ST. Results clearly indicated that E. gammiei possessed fibrinolytic activity which was very similar to ST activity. In SDS PAGE, prominent bands ranging from $44 \mathrm{KD}$ to $20 \mathrm{KD}$ were observed, Fig. 6. To confirm the fibrinolytic activity, zymography with fibrin was performed. In zymogram two bands, though diffused, were observed, indicating the presence of isozymes (Fig. 7)

Thrombolytic activity

Visual blood clot lysis is shown in Fig. 8. Negative control containing $\times 1$ PBS was mixed to blood clot, no obvious lysis was observed. Both standard ST (positive control) and homogenate increased the percentage of clot lysis in time-dependent manner. Highest clot lysis was observed with the addition of $100 \mu \mathrm{l}$ of standard ST containing
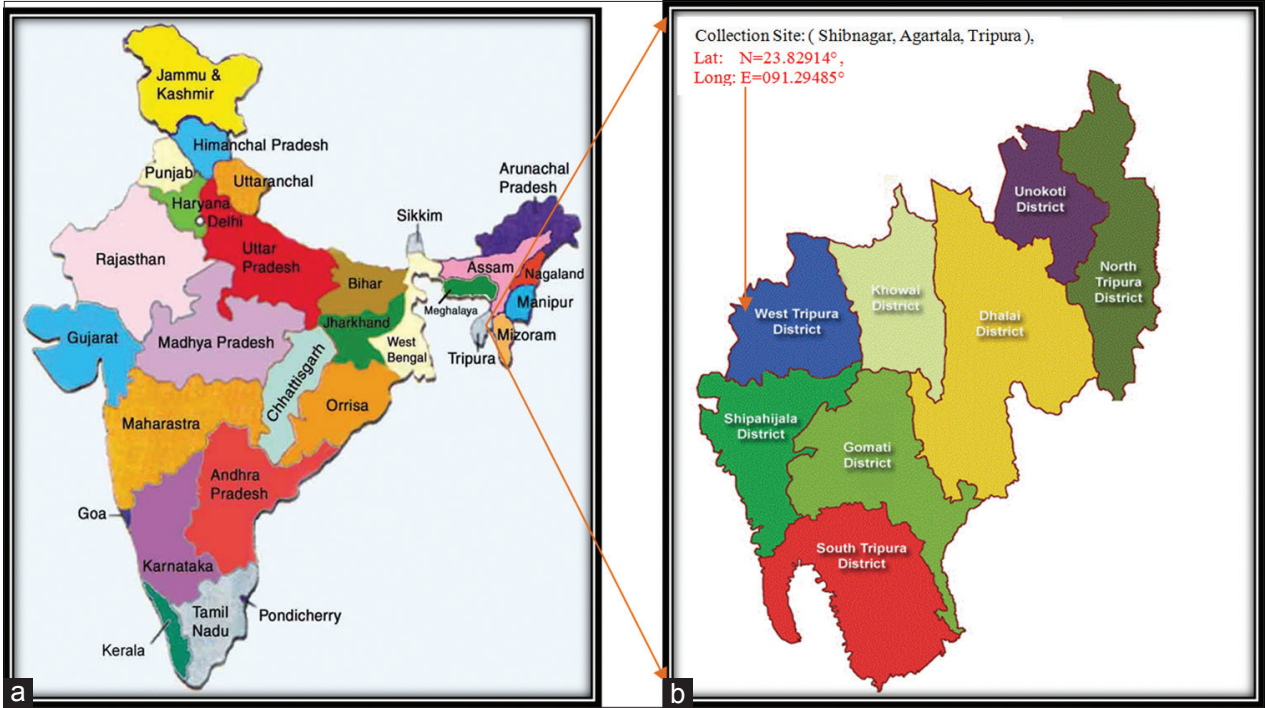

Fig. 2: Site of sample collection ([a] map of India and [b] map of Tripura showing the exact location of the site of collection) 


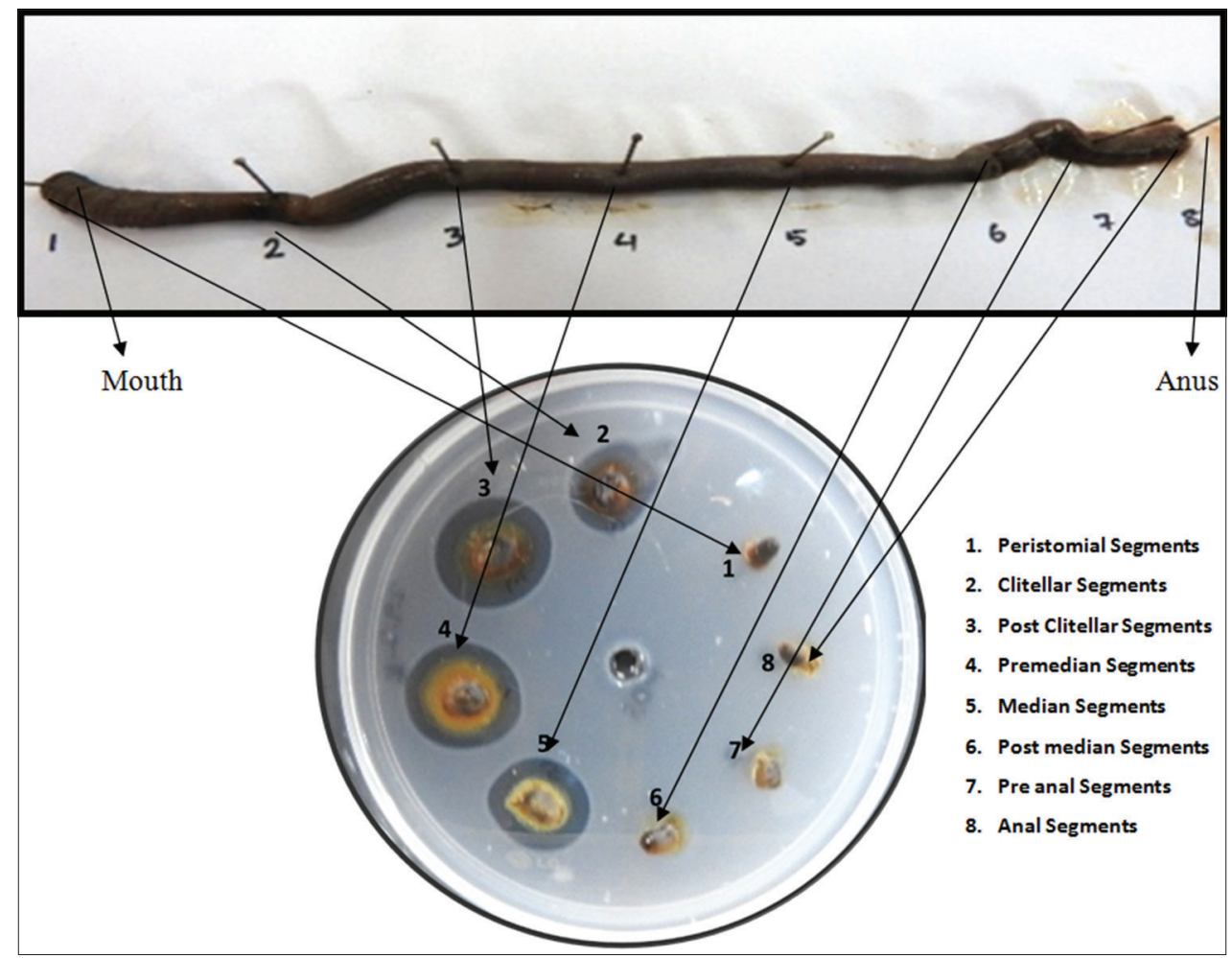

Fig. 3: Different parts of Eutyphoeus gammiei exhibit strong fibrinolysis. The sections were applied directly to the Petri dish plate containing artificial fibrin and incubated at $37^{\circ} \mathrm{C}$ overnight. Phosphate buffered saline was applied in the center well of the plate as negative controls. Bigger lysis halos $(2,3,4,5)$ indicated higher fibrinolytic activity regions

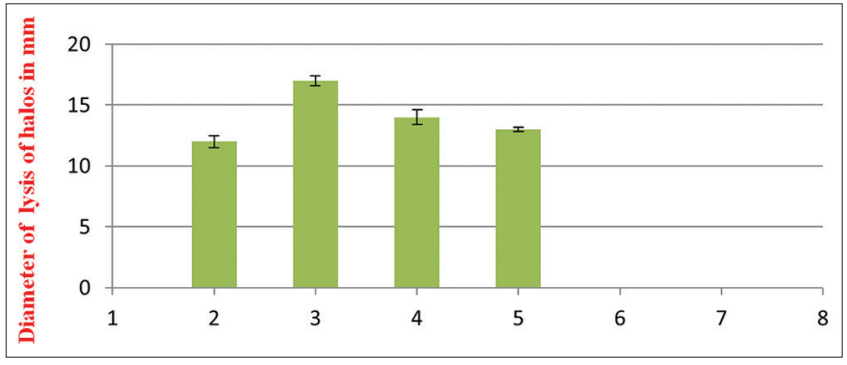

Fig. 4: Graphical representation of the fibrinolytic activity of different sections of Eutyphoeus gammiei

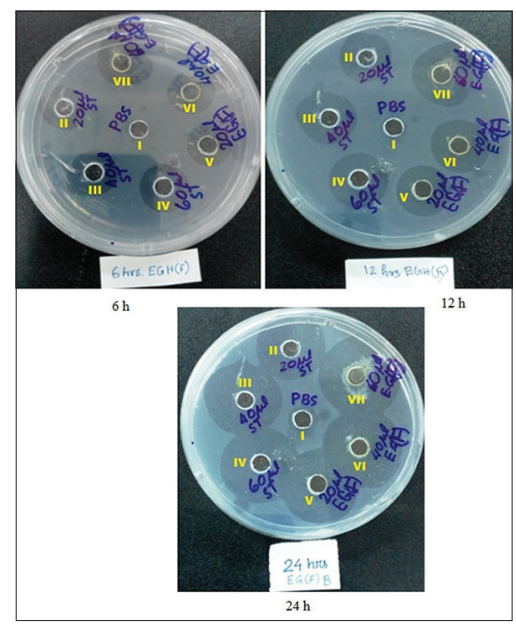

Fig. 5: Effect of homogenate of Eutyphoeus gammiei on fibrin plate at different incubation time interval. EGH: Eutyphoeus gammiei homogenate, ST: Streptokinase

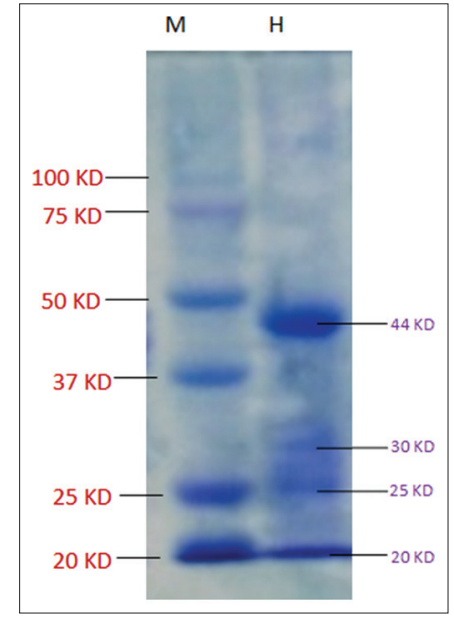

Fig. 6: Sodium dodecyl sulfate-poly acrylamide gel electrophoresis (10\%) of homogenate of earthworm Eutyphoeus gammiei M: Pre-stained protein marker (Biored), H: Homogenate of Eutyphoeus gammiei

3.7 International Unit/ $\mu \mathrm{l}$ and homogenate containing $0.5 \mathrm{mg} / \mathrm{ml}$, respectively.

\section{DISCUSSION}

Fibrinolytic enzymes dissolve fibrin, the main component of blood clots. Accumulation of fibrin in the blood vessels results in thrombosis, leading to myocardial infarction, and other heart diseases $[15,16]$ which are the leading causes of death throughout the world. Fibrinolytic enzyme has been successfully identified from various sources [17]. Fibrinolytic enzymes and thrombolytic agents currently available for clinical use, such as ST, urokinase, pro-urokinase, reteplase, and alteplase suffer significant unintended physiological 
effects such as excessive bleeding, short plasma half-life, limited fibrin specificity, and large therapeutic dose [18]. Therefore, search for less expensive and safer fibrinolytic enzymes and thrombolytic agents from other sources are still an urgent issue [19]. The scientists are always in search of biopotential compounds from natural sources for the treatment of various diseases. More and more researchers have focused on the analysis of bioactive proteins in earthworm coelomic fluid and glycolipoprotein powder [20]. The earthworm protease functions in the fibrinolysis and plasminogen activation have found to be associated with less side effects in comparison to that of urokinase, ST recombinant tissue-type plasminogen activator, etc., [21]. The protease during orally/administered experiments both in animals and clinical shows significant efficacy. The protease has been found to be stable during long-term storage at room temperature [22].

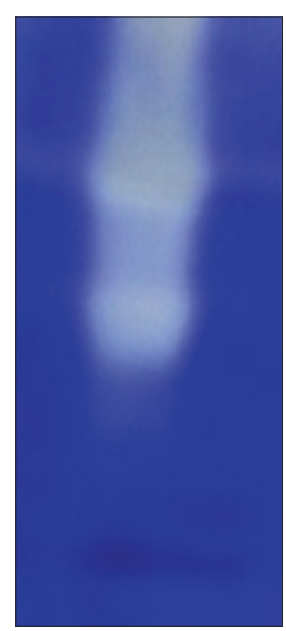

Fig. 7: Fibrin zymography with Eutyphoeus gammiei homogenate

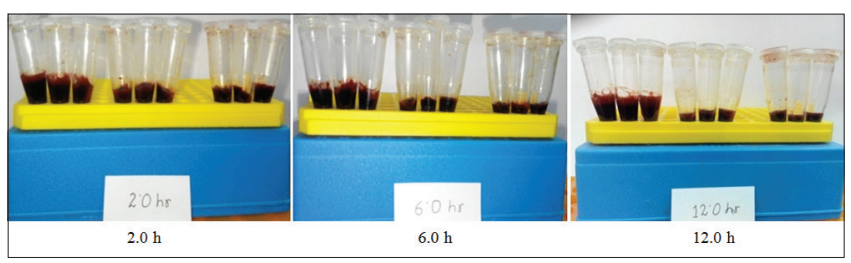

Fig. 8: Thrombolytic activity of homogenate of Eutyphoeus gammiei on human blood clot at a different time interval
However, because of the various living environment, different species of earthworms have different resultant isozymes [6]. Not many species of earthworms have been studied for fibrinolytic enzymes across the world.

In this study, E. gammiei an earthworm species native to North East India has been explored for fibrinolytic and thrombolytic potentiality. The results obtained (Table 1 and Figs. 4 and 5) clearly indicated E. gammiei as a potential source of fibrinolytic and thrombolytic agents. Both in fibrin plate assay and thrombolytic assay with whole blood, E gammiei crude homogenate showed similar and close results in respect to that of the standard drug in use ST. Fibrin zymography also showed antifibrinolytic activity with producing clear bands (Figs. 6 and 7). Dose and time dependency also was evident from the results. Further purification and characterization can lead to the clinical use of these enzymes. Therefore, along with other species, so far studied, E. gammiei collected from Northeastern part of India can also be a potential new source of fibrinolytic enzyme for clinical use.

\section{CONCLUSION}

The study suggested that crude extracts from earthworm of E. gammiei might prove to be useful alternative source for the development of new drugs for treatments involving blood clot and fibrinolysis. Further studies can now be designed to characterize and identify the protein of the E. gammiei extract involved in the fibrinolytic activity.

\section{ACKNOWLEDGMENT}

We are highly grateful to Prof P S Chaudhury, Department of Zoology, Tripura University, for his kind help regarding the identification of the organism (E. gammiei). Dr P Roy Choudhary, Research Associate, Sri Haridas Sutradhar, Lab Assistant, Department of Human Physiology, Tripura University, for technical help. The financial support for the work was extended by Tripura Biotechnology Council, Department of Science, Technology and Environment, Government of Tripura.

\section{AUTHORS' CONTRIBUTION}

Madhusudan Debnath is the main Researcher who had carried out the entire experiment including acquisition of data, analysis, and interpretation of data and drafted the manuscript. Susmita Saha, Research Scholar also helped M.S. Debnath during experiment as labmate. Prof. Samir Kr Sil is the Supervisor (guide) of the research work who had planned, designed, advised, and guided Sri M S Debnath during the implementation of the experiment as well as preparation of the manuscript.

Table 1: Data for comparative fibrinolytic effects of homogenate of Eutyphoeus gammiei on fibrin plate at different incubation period

\begin{tabular}{|c|c|c|c|c|c|c|}
\hline $\begin{array}{l}\text { EGH: Eutyphoeus gammiei } \\
\text { homogenate, } \\
\text { ST: Streptokinase }\end{array}$ & $\mathbf{0 H}$ & $2 \mathbf{H}$ & $6 \mathrm{H}$ & $12 \mathrm{H}$ & $18 \mathrm{H}$ & $24 \mathrm{H}$ \\
\hline EGH $20 \mu \mathrm{l}(10 \mu \mathrm{g})$ & 0 & $11.66 \pm 0.33$ & $15 \pm 0.57$ & $18.66 \pm 0.33$ & $24.66 \pm 0.33$ & $25.33 \pm 0.33$ \\
\hline ST $20 \mu \mathrm{l}$ & 0 & $12.33 \pm 0.33$ & $16.66 \pm 0.33$ & $19 \pm 0.57$ & $24.66 \pm 1.15$ & $27.00 \pm 1.00$ \\
\hline $\mathrm{EGH} 40 \mu \mathrm{l}(20 \mu \mathrm{g})$ & 0 & $12.66 \pm 0.33$ & $16.66 \pm 0.66$ & $20.33 \pm 0.33$ & $27.00 \pm 0$ & $28.66 \pm 0.66$ \\
\hline $\mathrm{ST} 40 \mu \mathrm{l}$ & 0 & $12.66 \pm 0.33$ & $18.33 \pm 0.88$ & $23.33 \pm 0.88$ & $28.00 \pm 1.00$ & $28.66 \pm 0.66$ \\
\hline EGH $60 \mu \mathrm{l}(30 \mu \mathrm{g})$ & 0 & $13.66 \pm 0.33$ & $19.33 \pm 0.67$ & $24.00 \pm 0.57$ & $29.33 \pm 2.85$ & $29.66 \pm 0.66$ \\
\hline
\end{tabular}

Mean \pm SD, n=3. EGH: Eutyphoeus gammiei homogenate, ST: Streptokinase, SD: Standard deviation

Table 2: Percentage of thrombolytic effect of Homogenate of Eutyphoeus gammiei

\begin{tabular}{|c|c|c|c|c|}
\hline $\begin{array}{l}\text { Control, } \\
\text { standard } \\
\text { and sample }\end{array}$ & $\begin{array}{l}\text { Thrombolytic effect of } \\
\text { Eutyphoeus gammiei after } \\
1 \mathrm{~h}\end{array}$ & $\begin{array}{l}\text { Thrombolytic effect of } \\
\text { Eutyphoeus gammiei after } \\
2 \mathrm{~h}\end{array}$ & $\begin{array}{l}\text { Thrombolytic effect of } \\
\text { Eutyphoeus gammiei after } \\
6 \mathrm{~h}\end{array}$ & $\begin{array}{l}\text { Thrombolytic effect of } \\
\text { Eutyphoeus gammiei after } \\
12 \mathrm{~h}\end{array}$ \\
\hline Control & $0 \%$ & $0 \%$ & $0 \%$ & $0 \%$ \\
\hline Streptokinase & $6 \pm 0.2$ & $41.77 \pm 0.02$ & $55.10 \pm 0.1$ & $57.14 \pm 0.02$ \\
\hline Homogenate & $2 \pm 0.2$ & $40.8 \pm 0.15$ & $51.02 \pm 0.01$ & $55.10 \pm 0.1$ \\
\hline
\end{tabular}




\section{CONFLICTS OF INTEREST}

The authors declared that they have no conflicts of interests among themselves.

\section{REFERENCES}

1. Vernooij MW, Haag MD, van der Lugt A, Hofman A, Krestin GP, Stricker BH, et al. Use of antithrombotic drugs and the presence of cerebral microbleeds: The Rotterdam scan study. Arch Neurol 2009;66:714-20

2. Delaney JA, Opatrny L, Brophy JM, Suissa S. Drug drug interactions between antithrombotic medications and the risk of gastrointestinal bleeding. CMAJ 2007; 177:347-51.

3. Nakajima N, Mihara H, Sumi H. Characterization of potent fibrinolytic enzymes in earthworm, Lumbricus rubellus. Biosci Biotechnol Biochem 1993;57:1726-30.

4. Ji H, Wang L, Bi H, Sun L, Cai B, Wang Y, et al. Mechanisms of lumbrokinase in protection of cerebral ischemia. Eur $\mathrm{J}$ Pharmacol 2008;590:281-9.

5. Fan Q, Wu C, Li L, Fan R, Wu C, Hou Q, et al. Some features of intestinal absorption of intact fibrinolytic enzyme III-I from Lumbricus rubellus. Biochim Biophys Acta 2001;3:286-92.

6. Rong P, Zhang ZJ, He RQ. Earthworm protease. Appl Environ Soc Sci 2010;2010:Article ID: 294258, 13 Pages.

7. Julka JM, Paliwal R, Kathireswari P. Biodiversity of Indian earthworms-an overview. In: Edwards CA, Jayaraaj $\mathrm{R}$, Jayraaj IA, editors. Proceedings of Indo-U $\mathrm{S}$ Workshop. Coimbatore, India: Vermitechnology in Human Welfare; 2009. p. 36-56.

8. Julka JM, Paliwal R, Kathireswari P. Biodiversity of Indian earthworms-an overview. In: Edwards CA, Jayaraaj $\mathrm{R}$, Jayraaj IA, editors. Proceedings of Indo-U $\mathrm{S}$ Workshop. Coimbatore, India: Vermitechnology in Human

9. Wowry OH, Rose p.brough NJ, Farr AL, Randall RJ. Protein measurement with the folin-phenol reagent. J Boil Chem 1951;193:265-75.

10. Astrup T, Mullertz S. The fibrin plate method for estimating fibrinolytic activity. Arch Biochem Biophys 1952;40:346-51.

11. Laemmli UK. Cleavage of structural proteins during the assembly of the head of bacteriophage T4. Nature 1970;227:680-5.

12. Kim SH, Choi NS, Lee WY. Fibrin zymography: A direct analysis of fibrinolytic enzymes on gels. Anal Biochem 1998;263:115-6.

13. Kleiner DE, Stetler-Stevenson WG. Quantitative zymography: Detection of picogram quantities of gelatinases. Anal Biochem 1994;218:325-9.

14. Prasad S, Kashyap RS, Deopujari JY, Purohit HJ, Taori GM, Daginawala HF, et al. Development of an in vitro model to study clot lysis activity of thrombolytic drugs. Thromb J 2006:4:14

15. Voet D and Voet JG. Biochemistry. New York, USA: John Wiley and Sons Press; 1990.

16. Kim W, Choi K, Kim Y, Park H, Choi J, Lee Y, et al. Purification and characterization of a fibrinolytic enzyme produced from bacillus sp. Strain CK 11-4 screened from chungkook-jang. Appl Environ Microbiol 1996;62:2482-8

17. Takeno T, Okamura T, Sera M, Takana M, Fukuda S, Ohsugi M, Screening of fibrinolytic enzyme of microorganisms. Bull Mukogawa's Univ Nat Sci 1999;47:67-72.

18. Mackman N. Triggers targets and treatments for thrombosis. Nature 2008;451:914-18.

19. Rashad MM, Mahmoud AE, AI-Kashef AS, Mohamed UN. Purification and characterization of a novel fibrinolytic enzyme by Candida guilliermondii grown on sunflower oil cake. J Appl Sci Res 2012;8:635- 45.

20. Anjana JC, Sruthy P, Rathinamala J, Jayashree S. In vitro evaluation of glycolipoprotein powder from earthworm Eudrilus engeniae. Int J Pharm Pharm Sci 2015;7:377-9.

21. Kim JS, Kang JK, Chang HC, Lee M, Kim GS, Lee DK, et al. The thrombolytic effect of lumbrokinase is not as potent as urokinase in a rabbit cerebral embolism model. J Korean Med Sci 1993;8:117-20.

22. Nakajima N, Sugimoto M, Ishihara K. Stable earth-worm serine proteases, application of the protease function and usefulness of the earthworm autolysate. J Biosci Bioeng 2000;90:174-9. 